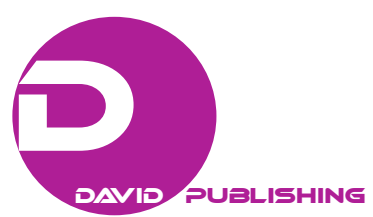

\title{
The Music in Uludag University From Asia to Balkans*
}

\author{
Asım YEDIYILDIZ, Şirin AKBULUT DEMIRCI \\ Uludag University, Bursa, Turkey
}

\begin{abstract}
This paper is about the results of the project, "The Music in Uludag University from Asia to Balkans". In this project, cultures and traditional music of foreign students who are educated in Uludag University were searched. The students who also play or sing their music were chosen from Indonesia, Republic of Bashkortostan, Afghanistan, Pakistan, Egypt, Morocco, Ethiopia, Macedonia, Albania, Kosovo, and Bosnia Herzegovina. They had studied and practiced music for six weeks. In May 2015, they introduced their music with big organization host in campus concert hall organized by Uludag University, Turkish State and Relatives Community Applications and Research Center. These chosen students introduced their countries with their music and at the end of the concert in this research the outcomes and results of multicultural activity were examined. This paper was presented at 2015 West East Institute Academic Conference and the full paper was published at proceeding book.
\end{abstract}

Keywords: music, multicultural, Asia, Balkans

\section{Introduction}

The project "The music Lives in The Campus from Asia to Balkans" was run with Turkish State and Relatives Community Applications and Research Center. According to the center data, there are nearly two thousand students from ninety three foreign countries in Uludag University. The aim of the project is to search the students' cultures, their traditional music, music instruments, and traditional folk songs. Thus, it is thought that the period witnessed a great musical journey, starting from Asia to the Balkans. In particular, the social sciences and humanities, generally, university and community members, with traditional music to contribute through scientific research and hands-on activities related to musical culture and tradition and also with the music of the mediator feature is intended to create a unifying effect on society. In addition to traditional music (especially traditional folk music) in areas including research, to ensure the research and application, and thus giving the work done at the academic level to address deficiencies in this area is to organize activities at national level.

Material and methods are a concert event in the study that was carried out to obtain data and surveys to determine that their views on the activities carried out were applied to the participating students.

According to the project's duration which is one year and the project's planned duration of the timetable set by executive order stage are as follows:

(1) At the beginning of the year 2013-2014, foreign students who are educated in Uludag University were informed and eager students to be involved in the project were determined by the meeting. Two hundred and

\footnotetext{
* Acknowledgements: This article had the outcomes of the project KUAP (TÜDAM)—2014/31 numbered, which was supported by Uludag University Scientific Research Projects Unit, with offer our thanks.

Asım YEDIYILDIZ, Professor, Islamic Art History Department, Faculty of Theology, Uludag University.

Şirin AKBULUT DEMIRCI, Accosiated Professor, Music Education Department, Faculty of Education, Uludag University.
} 
forty five students filled the survey and 31 of them were chosen for the project.

(2) The second week of January 2015 until the beginning of March, in six weeks students who were from Asia to the Balkans and were chosen for the project, the students' music cultures, the popular types of music's, their instrument types, and the compilation of the songs they sang were searched. Also 12 students from Uludag University Music Education Department were chosen for the project choir and studied Turkish song with foreign students for the final concert event.

(3) Planning with the participation of the students identified in April a concert event. And prepared questionnaire for a concert participants will be given to determine the views of the students.

(4) In 7th May 2015, concert event was organized and was staged. Fifty foreign students (23 Indonesian, one student from Republic of Bashkortostan, four Afghan, five Pakistani, one Egyptian, two Moroccan, one Ethiopian, three Macedonian, six Albanian, four from Bosnia-Herzegovina) introduced their countries with music or dance and also with eight more foreign students and 12 Turkish students were on stage with all the others sang Turkish songs as a choir. ${ }^{1}$ Following a concert participants were given a questionnaire to determine the views of the students 32 of them and answers.

(5) The findings were analyzed and prepared them for an international publication.

\section{Results}

These data are the outcomes of the project. The survey was given to 60 students and 31 answers. Some of them were not capable of understanding the survey because they have just learned Turkish and cannot understand the questions clearly and did not answer them.

The students' thoughts about "What are your thoughts about the Project the 'Music from Asia to the Balkans lives on the Campus?" are as fallows.

Table 1

The Findings of the Question About if They Are Pleased to Take Part in the Project

\begin{tabular}{llllll}
\hline & Strongly agree & Agree & Partially agree & Disagree & Strongly disagree \\
\hline \multirow{2}{*}{ I am pleased to take part in the project } & $27^{2}$ & 4 & & \\
& $\% 87$ & $\% 12$ & & \\
\hline
\end{tabular}

According to the data of Table 1, \%87 of the students strongly agree and $\% 12$ of the student agree and in total all students are pleased to take part in the project.

Table 2

The Findings of the Question About if They Had the Opportunity to Introduce Their Country With the Slide Presentations

\begin{tabular}{|c|c|c|c|c|c|}
\hline & Strongly agree & Agree & Partially agree & Disagree & Strongly disagree \\
\hline I had the opportunity to introduce my & 14 & 10 & 5 & & 2 \\
\hline country with the slide presentation & $\% 45.1$ & $\% 32$ & $\% 16.1$ & & $\% 6.4$ \\
\hline
\end{tabular}

According to the data of Table 2 the $\% 45.1$ students strongly agree with high frequency that they introduce their country with slide presentation. \%6.4 with lowest two frequencies strongly disagrees because they were only in the choir singing Turkish songs so they had not opportunity to introduce their country with slide

\footnotetext{
${ }^{1}$ For the announcement of the event, see from https://www.facebook.com/events/1584577578488203/; for the video from the event, see from https://www.youtube.com/watch?v=bwvBuP9a9TA.

${ }^{2}$ First numbers are the frequencies, second ones are the percent's of the results.
} 
presentation.

Table 3

The Findings of the Question About if They Had the Opportunity to Introduce Their Country With the Instruments They Played

\begin{tabular}{llllll}
\hline & Strongly agree & Agree & Partially agree & Disagree & Strongly disagree \\
\hline I had the opportunity to introduce my & 9 & 5 & 2 & 5 & 8 \\
country with the instruments I played & $\% 31$ & $\% 17.2$ & $\% 6.8$ & $\% 17.2$ & $\% 27.5$ \\
\hline
\end{tabular}

According to the data of Table 3 strongly agree have highest frequency with nine and strongly disagree with eight frequency are the second highest frequency. According to it 16 students with in total \% 55 introduced their countries with instruments they played.

Table 4

The Findings of the Question if They Had the Opportunity to Represent Their Country by Singing Their Traditional Songs

\begin{tabular}{llllll}
\hline & Strongly agree & Agree & Partially agree & Disagree & Strongly disagree \\
\hline I had the opportunity to represent my & 17 & 7 & 2 & 1 & 4 \\
country by singing our traditional songs & $\% 54.8$ & $\% 22.5$ & $\% 6.4$ & $\% 3.2$ & $\% 12$ \\
\hline
\end{tabular}

According to the data of Table 4 strongly agree has highest frequency with $\% 54.8$ and lowest frequency with \%3.2. In total 26 students $\% 83.7$ they had opportunity to represent their country by singing their traditional songs.

Table 5

The Findings of the Question if They Had the Opportunity to Represent Their Country With Their Traditional Clothes

\begin{tabular}{llllll}
\hline & Strongly agree & Agree & Partially agree & Disagree & Strongly disagree \\
\hline I had the opportunity to represent my & 17 & 8 & 4 & 2 & $\% 6.4$ \\
country with our traditional clothes & $\% 54.8$ & $\% 27.5$ & $\% 12$ & $\%$ \\
\hline
\end{tabular}

According to the data of Table 5 in total 29 students with \%94.3 had opportunity to represent their country with their traditional clothes.

Table 6

The Findings of the Question if They Were Proud to Get the Opportunity to Introduce Their Country

\begin{tabular}{|c|c|c|c|c|c|}
\hline & Strongly agree & Agree & Partially agree & Disagree & Strongly disagree \\
\hline $\begin{array}{l}\text { I was proud to get the opportunity to } \\
\text { introduce my country }\end{array}$ & $\begin{array}{l}26 \\
\% 83.8\end{array}$ & $\begin{array}{l}3 \\
\% 9.6\end{array}$ & $\begin{array}{l}1 \\
\% 3.2\end{array}$ & & $\begin{array}{l}1 \\
\% 3.2\end{array}$ \\
\hline
\end{tabular}

According to the data of Table $6 \% 83.8$ students with high frequency strongly agree that they were proud to get opportunity to introduce their country.

Table 7

The Findings of the Question if They Were Happier to Receive Further Training in the Uludag University

\begin{tabular}{llllll}
\hline & Strongly agree & Agree & Partially agree & Disagree & Strongly disagree \\
\hline I was happier to receive further training in & 16 & 11 & 4 & & \\
\hline
\end{tabular}




the UU $\quad \% 51.6 \quad \% 35.4 \quad \% 12$

According to the data of Table 7 strongly agree has highest frequency with \%51.6. In total of positive opinions all students were happier to receive further training in the UU.

Table 8

The Findings of the Question if They Had the Opportunity to Work With Students From Different Countries Under the Project

\begin{tabular}{llllll}
\hline & Strongly agree & Agree & Partially agree & Disagree & Strongly disagree \\
\hline I had the opportunity to work with students & 19 & 9 & 2 & 1 & \\
from different countries under the project & $\% 61.2$ & $\% 29$ & $\% 6.4$ & $\% 3.2$ & \\
\hline
\end{tabular}

According to the data of Table 8 strongly agree has highest frequency with $\% 61.2$ and positive opinions have 30 frequencies with $\% 96.6$ in total.

Table 9

The Findings of the Question if With the Project They Had an Opportunity to Sing and Learn Turkish Songs

\begin{tabular}{|c|c|c|c|c|c|}
\hline & Strongly agree & Agree & Partially agree & Disagree & Strongly disagree \\
\hline $\begin{array}{l}\text { With the project I had an opportunity to sing } \\
\text { and learn Turkish songs }\end{array}$ & $\begin{array}{l}11 \\
\% 35.4\end{array}$ & $\begin{array}{l}11 \\
\% 35.4\end{array}$ & $\begin{array}{l}8 \\
\% 27.5 \\
\end{array}$ & & \\
\hline
\end{tabular}

According to the data of Table 9 strongly agree and agree have same highest frequency with\%35.4 and in total all participants think that with the project they had an opportunity to sing and learn Turkish songs.

Table 10

The Findings of the Question if the Project Final Event's Organization Was Successful

\begin{tabular}{llllll}
\hline & Strongly agree & Agree & Partially agree & Disagree & Strongly disagree \\
\hline The project final event's organization was & 18 & 9 & 3 & & \\
successful & $\% 58$ & $\% 31$ & $\% 9.6$ & \\
\hline
\end{tabular}

According to the data of Table 10 strongly agree has highest frequency with $\% 58$ and partially agree has the lowest frequency with \%9.6 all participants thought the finishing project event's organization was successful.

Table 11

The Findings of the Question if They Would Like to Take Place on the Same Project Again

\begin{tabular}{|c|c|c|c|c|c|}
\hline & Strongly agree & Agree & Partially agree & Disagree & Strongly disagree \\
\hline $\begin{array}{l}\text { I would like to take place on the same project } \\
\text { again }\end{array}$ & $\begin{array}{l}29 \\
\% 93.5\end{array}$ & $\begin{array}{l}2 \\
\% 66.8\end{array}$ & & & \\
\hline
\end{tabular}

According to the data of Table 11 all the participants have positive opinion and would like to take place on the same project again.

Table 12

The Findings of the Question if They Think This Project Socialize Them

\begin{tabular}{llllll}
\hline & Strongly agree & Agree & Partially agree & Disagree & Strongly disagree \\
\hline \multirow{2}{*}{ I think this project socialize me } & 19 & 9 & 2 & & \\
\hline
\end{tabular}

According to the data of Table 12 all the participants thought this project socialize them. 
Table 13

The Findings of the Question if They Found Successful, the Work Done for the Project

\begin{tabular}{llllll}
\hline & Strongly agree & Agree & Partially agree & Disagree & Strongly disagree \\
\hline I found successful, the work done for the & 21 & 10 & & \\
project. & $\% 67.7$ & $\% 32.2$ & & \\
\hline
\end{tabular}

According to the data of Table 13 all participants found the work done for the project successful.

Table 14

The Findings of the Question if They Think the Project Final Event Is Represented the Countries of the Project in the Best Way

\begin{tabular}{|c|c|c|c|c|c|}
\hline & Strongly agree & Agree & Partially agree & Disagree & Strongly disagree \\
\hline $\begin{array}{l}\text { I think the Project final event is represented } \\
\text { the countries of the project in the best way }\end{array}$ & $\begin{array}{l}11 \\
\% 35.4\end{array}$ & $\begin{array}{l}20 \\
\% 64.5\end{array}$ & & & \\
\hline
\end{tabular}

According to the data of Table 14 all participants thought that the project final event is represented the countries of the project in the best way.

Table 15

The Findings of the Question if They Think to Be Involved in the Project Contribute Them

\begin{tabular}{lllccc}
\hline & Strongly agree & Agree & Partially agree & Disagree & Strongly disagree \\
\hline I think to involved in the Project contribute & 20 & 11 & & \\
me & $\% 64.5$ & $\% 35.4$ & & \\
\hline
\end{tabular}

According to the data of Table 15 all participants thought to be involved in the Project contribute them.

There were three open ended questions about their positive and negative opinions and their suggestions.

According to positive opinions of the data, they wrote that from the highest frequency to the lowest introduce their country has nine frequency, socialized me has five frequency, it was good to identify different cultures has four frequency, the foreign students do not feel alone has four frequency, the helpfulness of the teacher has two frequency, preparation was successful has two frequency, it was fun and it contribute me has one frequency.

According to negative opinions the highest frequency is six, they think there should be more people watching them, the slide presentation should be longer which has two frequency and one student wrote that all students should have their traditional dresses.

According to the suggestions, eight participants wanted this event to become traditional, four of them recommended to stage at bigger hall, three participants recommended to advertise more, two participants wrote that more people should be watching and one of them wanted the concert to be longer.

\section{Conclusion}

In conclusion, participants' outcomes after the project have positive opinions as they are pleased to take part in the project $(\% 100)$, they introduced their country with slide presentation (\%93.2), they introduced their countries with instruments they played (\%55), they had opportunity to represent their country by singing their traditional songs (\%83.7), they had opportunity to represent their country with their traditional clothes (\%94.3), they were proud to get opportunity to introduce their country $(\% 83.8)$, they were happier to receive further 
training in the UU (\%100), they had the opportunity to work with students from different countries under the project (\%96.6), they had an opportunity to sing and learn Turkish songs (\%100), they thought the finishing project event's organization was successful $(\% 100)$, they would like to take place on the same project again (\%100), they thought this project socialize them (\%100), they found the work done for the project successful $(\% 100)$, they thought that the project final event represented the countries of the project in the best way (\%100), they thought that involved in the Project contributed them (\%100). Also students wrote these as appositive opinions introduced their country, socialized them, it was good to identify different cultures, the foreign students did not feel alone, the helpfulness of the teacher, preparation was successful, it was fun and it contributed them.

The negative opinions are these: They think there should be more people watching them, the slide presentation should be longer and one student wrote that all students should have their traditional dresses.

Suggestions are this event to become traditional, recommended to stage at bigger hall, to advertise more and more people should be watching and one of them wants the concert to be longer.

As a summary, the project was successful with successful outcomes.

\section{References}

http://tudam.uludag.edu.tr/ (May 2015)

https://www.youtube.com/watch?v=bwvBuP9a9TA (May 2015)

https://www.facebook.com/events/1584577578488203/ (May 2015) 


\section{Appendix A: Brief Biographies}

Prof. M. Asım Yediyıldız graduated from Ondokuz Mayıs University Faculty of Theology in 1984 and Hacettepe University Theology master degree in 1989 and at same place doctorate degree in 1995. He had been vice-dean between 1998-2001 in Turkmenistan Magtımgulı University and between 2007-2009 in Uludag University, Faculty of Theology. He had been the head of Turkish State and Relatives Community Applications and Research Center until 2015. He wrote eleven articles, six books, six book chapters and made more than fifteen presentations at conferences. He is currently working in Uludag University Islamic Art History Department as a Professor.

Assoc. Prof. Şirin Akbulut Demirci studied at Bursa Fine Arts School in Bursa. She graduated from Bursa Uludag University in 2001. She won Third Prize at the International Young Musicians Piano Competition in 2000. Akbulut Demirci studied piano in France and earned the Prof. Desire N'Kaoua Honor Certificate. Later she completed her Master in Art in Trakya State Conservatory in Edirne and DMA degree in Mimar Sinan State Conservatory in Istanbul. She was appointed Research Assistant at both Mimar Sinan Fine Art University and Bursa Uludag Universities. She won Uludag University Art Award in 2012, Performance Award in 2013 and Project Award in 2014. She is currently working as Associate Professor at Bursa Uludag University, giving lots of concerts as a performer in Turkey, Hungary, Italyetc and also made presentations in lots of International Conferences. 